\title{
Effects on Compressive Strength on Using Palm Oil Clinker as Partial Replacement of Fine Aggregate in Concrete
}

\author{
Arunima V $\mathbf{R}^{1}$, Sreelekshmi $S^{2}$ \\ ${ }^{1}$ Project Scholar, Department of Civil Engineering, Sree Buddha College of Engineering, Pattoor P.O, Nooranad, Alappuzha-690529, India \\ ${ }^{2}$ Assistant Professor, Department of Civil Engineering, Sree Buddha College of Engineering, Pattoor, Alappuzha
}

\begin{abstract}
With an expanding global population fuelling the need for housing and infrastructure, natural sand is being extracted at an increasing rate. As a result of over-exploration, river sand is in short supply in many parts of the world and the construction industry faces difficulties in achieving targets. This warrants the need for alternatives to river sand to bridge the gap between demand and supply. The present study reveals the use of Palm Oil Clinker, a waste byproduct from palm oil industry, as an alternative material to fine aggregate in concrete production. The primary objective of this study is to conduct compressive strength test on M30 concrete for palm oil clinker replacement proportions of 0\%, 5\%, 10\%, 15\%, 20\% and 25\% by weight of fine aggregate. The 7 day and 28 day compressive strength tests were conducted on concrete cube specimens to obtain the optimal percentage replacement. The results indicated that the concrete specimens containing up to $20 \%$ palm oil clinker by weight of fine aggregate showed higher compressive strength development than traditional concrete.
\end{abstract}

Keywords: Compressive strength, Fine aggregate, Global population, Palm oil clinker

\section{Introduction}

Concrete is a composite material composed of aggregates, cement and water. Aggregates are the important constituents in concrete .The size of aggregate bigger than $4.75 \mathrm{~mm}$ is considered as coarse aggregate and aggregate whose size is $4.75 \mathrm{~mm}$ and less is considered as fine aggregate. Natural river sand as fine aggregate is the most important resource utilized by the construction industry for concrete production. The consumption of natural river sand as fine aggregate by the growing population is very high and several countries have encountered shortage of natural fine river sand .The ever increasing population and economic developments impose an exponential rise in demand for natural river sand throughout the world.

On the other side, the quality of the environment is deteriorating every day. The world is becoming increasingly conscious of environment problems caused by the release of hazardous wastes from industries. Many researchers came up with the idea of using industrial waste materials such as lime stone waste, marble powder, furnace slag, stone dust etc as alternative materials for fine aggregate.

Palm oil clinker is an industrial byproduct from palm oil industry produced abundantly can be considered as alternative to natural sand as they have similar physical and chemical properties of natural sand. The effectiveness of using palm oil clinker as replacement material for fine aggregate reduces the problem of environmental pollution to a greater extend with decreased cost of construction. M.Adaway [1] studied the variation of compressive strength on using recycled glass as replacement material for fine aggregate in structural concrete. Recycled glass was introduced into the concrete mix at different levels of replacement such as $0 \%, 15 \%, 20 \%, 25 \%, 30 \%$ and $40 \%$ of fine aggregate in concrete. An increase in compressive strength was observed for the mixes containing recycled glass as compared to normal concrete. Maximum strength development was observed at $30 \%$ partial replacement of fine aggregate by recycled glass.

Sumeet [2] conducted experiments to study the strength and durability of concrete with partial replacement of fine aggregate by pond ash .Pond ash obtained as the by-product of thermal industry was introduced into the concrete mix at different levels of replacement such as $0 \%, 10 \%, 20 \%, 30 \%$ and $40 \%$ of fine aggregate in concrete. An increase in compressive strength, flexural strength and split tensile strength was observed for the mixes containing pond ash compared to the conventional concrete specimens. The maximum strength was observed at $30 \%$ partial replacement of fine aggregate by pond ash. The study concludes that the use of pond ash is suitable for construction industries and is also environmental friendly. Bashar S. Mohammed et al. [3] conducted a durability test known as rapid chloride permeability test on concrete specimens incorporating palm oil clinker. The specimens were prepared by fully replacing the fine and coarse aggregate using palm oil clinker aggregates. All the strength test results indicated the feasibility of using palm oil clinker in light weight aggregate concrete. Rapid chloride permeability test was conducted at 7day, 28day and 90 day. A high value of chloride ion penetration was observed at 7 day and 28 day whereas moderate value was observed at 90 day.

F .A. Oluto [4] studied the behaviour of concrete slab incorporating sawdust and palm kernel as replacement material for fine and coarse aggregate respectively .The study revealed the production of light weight concrete slabs at a lower replacement value of $25 \%$ sawdust and palm kernel shell. Divakar.Y et al. [5] studied the use of granite fines as a replacement material for fine aggregate. Replacement of fine aggregate was carried out in five proportions such as $5 \%, 15 \%, 25 \%, 35 \%$, and $50 \%$. Compressive strength test, split tensile strength test and 


\section{International Journal of Science and Research (IJSR) \\ ISSN (Online): 2319-7064}

Index Copernicus Value (2013): 6.14 | Impact Factor (2015): 6.391

flexural strength test were conducted and the overall increase in the strength was observed for $35 \%$ replacement level of fine aggregate using granite fines.

K. Muthuwamy et al. [6] studied the use of crushed palm oil shell as a replacement material for fine aggregate in concrete. Crushed palm oil shell was introduced in the concrete specimens as partial sand replacement material ranging from $0 \%, 25 \%, 50 \%, 75 \%$ and $100 \%$. As the crushed palm oil shell replacement level increased, the compressive strength and density decreased. The study revealed the optimum percentage that can be adopted for structural concrete was around $25 \%$ of crushed palm oil shell.

\section{Experimental Work}

Concrete mix design was done according to Indian Standard Recommended Method IS 10262-2009. The mixes were proportioned to achieve target mean strength of $30 \mathrm{Mpa}$ after 28 days and the mix proportion was obtained as $1: 1.586: 2.527$. Water cement ratio was kept constant as 0.45 . Concrete mix with $0 \%$ palm oil clinker was considered as the control mix and other five mixes consisting of 5\%, $10 \%$, $15 \%, 20 \%$ and $25 \%$ palm oil clinker by weight of fine aggregate were prepared. Table 1 gives the summary of concrete mix design.

Table1: Mix design

\begin{tabular}{|c|c|c|c|c|}
\hline Material & Cement & $\begin{array}{c}\text { Fine } \\
\text { aggregate }\end{array}$ & $\begin{array}{c}\text { Coarse } \\
\text { aggregate }\end{array}$ & Water \\
\hline Weight $\left(\mathrm{kg} / \mathrm{m}^{3}\right)$ & 438 & 695 & 1107 & 197 \\
\hline Ratio & 1 & 1.586 & 2.527 & 0.45 \\
\hline
\end{tabular}

Ordinary Portland Cement(OPC) of 43 grade was used. Various physical properties were determined and the results are shown in Table 2.

Table 2: Physical properties of OPC

\begin{tabular}{|c|c|}
\hline Particulars & Values \\
\hline Grade & OPC43 \\
\hline Specific gravity & 3.2 \\
\hline Standard consistency & 33 \\
\hline Fineness & 1 \\
\hline Initial setting time (min) & 60 \\
\hline Final setting time(min) & 360 \\
\hline
\end{tabular}

M sand was used as fine aggregate. Laboratory tests were conducted on fine aggregate to determine the physical properties as per IS 2386(Part III)-1970.The results are indicated in Table 3. Locally supplied granite type coarse aggregates were used in the study. Laboratory tests were conducted on coarse aggregate to determine the physical properties as per IS 2386(Part III)-1963. The results are indicated in Table 4.

Table3: Physical properties of MSand

\begin{tabular}{|c|c|}
\hline Property & Value \\
\hline Fineness modulus & 3.15 \\
\hline Specific gravity & 2.61 \\
\hline Sieve analysis & Zone of aggregate-Zone I \\
\hline
\end{tabular}

Volume 5 Issue 6, June 2016 www.ijsr.net

Licensed Under Creative Commons Attribution CC BY
Table4: Physical properties of coarse aggregate

\begin{tabular}{|c|c|}
\hline Property & Value \\
\hline Fineness modulus & 0.92 \\
\hline Specific gravity & 2.88 \\
\hline Bulk density $(\mathrm{g} / \mathrm{cc})$ & 1.64 \\
\hline Porosity $(\%)$ & 43 \\
\hline Void ratio & 0.75 \\
\hline
\end{tabular}

The raw material Palm oil clinker used in the study was collected from palm oil mill located at Bharatheepuram of Kollam district, Kerala, India. Palm oil clinker was taken out from the furnace and left to cold after being burnt for 4 hours at $400^{\circ} \mathrm{C}$. Laboratory tests were conducted to determine the physical properties of palm oil clinker and are indicated in Table 5. The results of gradation test conducted on Msand and palm oil clinker are summarized in Table 6.

Table5: Physical properties of palm oil clinker

\begin{tabular}{|c|c|}
\hline Property & Value \\
\hline Fineness modulus & 2.59 \\
\hline Specific gravity & 2.75 \\
\hline Sieve analysis & Zone of aggregate-Zone II \\
\hline
\end{tabular}

Table6: Gradation of Msand and palm oil clinker

\begin{tabular}{|c|c|c|}
\hline \multirow{2}{*}{ Sieve size $(\mathrm{mm})$} & \multicolumn{2}{|c|}{ Cumulative percentage weight passing (\%) } \\
\cline { 2 - 3 } & MSand & Palm oil clinker \\
\hline 4.75 & 100 & 100 \\
\hline 2.36 & 88.6 & 95.3 \\
\hline 1.18 & 56.9 & 74.8 \\
\hline 0.6 & 32.2 & 46.6 \\
\hline 0.3 & 7.2 & 18.4 \\
\hline 0.15 & 0.4 & 5.5 \\
\hline
\end{tabular}

Clean drinking water available in the college water supply system was used for casting and curing of specimens.

\section{Experimental Test Method}

Experimental investigations on compressive strength were conducted based on IS: 516-1959. Compressive strength is the most important property of hardened concrete and is generally considered in the design of concrete mixes. Testing of hardened concrete is important for controlling the quality of concrete. Many other properties of concrete depend on its compressive strength.

Compression test on cube specimen is the most common test conducted on hardened concrete because it is an easy test to perform and most of the desirable properties of concrete are comparatively related to its compressive strength. In the present study, a total of 36 cubical specimens of size $150 \mathrm{~mm}$ x $150 \mathrm{~mm}$ x $150 \mathrm{~mm}$ were adopted to conduct compressive strength test .The cube specimens were tested in a compression testing machine of capacity $2000 \mathrm{kN}$, at a loading rate of $14 \mathrm{~N} / \mathrm{mm}^{2}$ per minute. The test was carried out for all six proportion of mix and the corresponding 7 day and 28 day compressive strength was obtained.

\section{Experimental Results and Discussions}

The average value for 7 day compressive strength of 


\section{International Journal of Science and Research (IJSR) \\ ISSN (Online): 2319-7064}

Index Copernicus Value (2013): 6.14 | Impact Factor (2015): 6.391

concrete obtained for the specimens can be seen below in Fig.1. The 7 day compressive strength of control mix was obtained as $21.11 \mathrm{Mpa}$. The results indicated an increase in the average 7 day compressive strength with the addition of palm oil clinker, until the maximum compressive strength (27.85 Mpa) was developed at a replacement level of $20 \%$. Beyond 20\%, reduction in compressive strength was observed (23.26 Mpa) but still higher than the control mix.

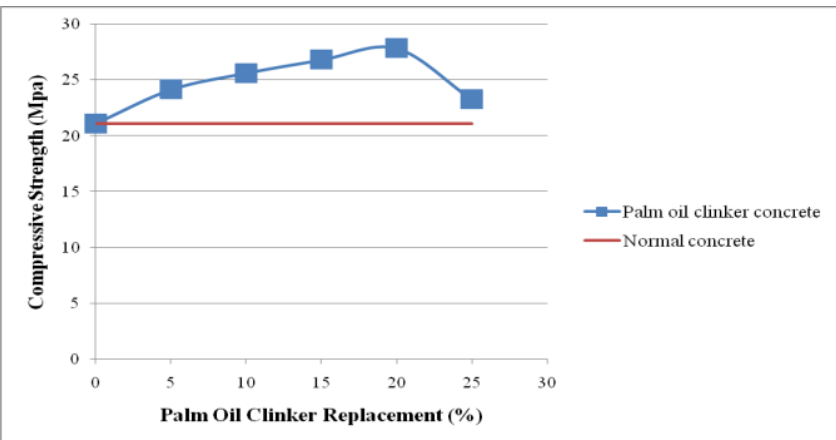

Figure 1: Comparison of 7 day compressive strength between normal concrete and palm oil clinker concrete

The average value for 28 day compressive strength of concrete specimens can be seen below in Fig.2. The test specimen with $20 \%$ inclusion of palm oil clinker yielded the highest average 28 day compressive strength of $54.96 \mathrm{Mpa}$ compared with $38.15 \mathrm{Mpa}$ for the control mixture, whereas the lowest compressive strength of $40.15 \mathrm{Mpa}$ was obtained for the mixture containing $25 \%$ palm oil clinker inclusion.

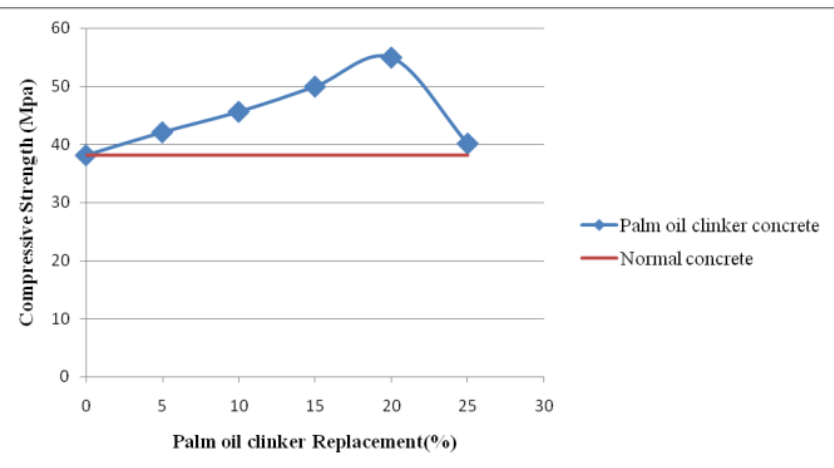

Figure 1: Comparison of 28 day compressive strength between normal concrete and palm oil clinker concrete

Palm oil clinker has better compressibility than sand, which can partially relieve the stress concentration, if the sand is still the dominant fine aggregate holding the concrete matrix together. Angular sharp edges of palm oil clinker particles can improve the cohesion of concrete matrix. On the other hand, glassy surface texture of palm oil clinker particles has a negative effect on the cohesion. Low absorption properties of palm oil clinker can leave excess water in concrete which can cause excessive bleeding at higher palm oil clinker content. This results in the formation of internal voids and capillary channels in the concrete, causing a reduction in its quality.

Therefore, strength of concrete with lower palm oil clinker content can be improved by the positive effect of palm oil clinker, whereas if palm oil clinker content exceeds $20 \%$, the strength of concrete decreases substantially with reduction in cohesion governed by palm oil clinker.

It is known that the sand has good abrasion properties because of its rough surface, which can improve the cohesion between the cement paste and coarse aggregate. However, the abrasion properties of sand is weakened with time after years of weathering causing sand particles to have rounded edges, which are detrimental to the interlocking properties of composite materials. Angular sharp edges of palm oil clinker particles have the ability to compensate to some extend the adverse effects of sand and thus improve the cohesion of concrete.

\section{Conclusion}

In this study, utilization of palm oil clinker as a partial replacement material for fine aggregate in structural grade concrete was analyzed. The optimum percentage replacement of sand with palm oil clinker was determined to be $20 \%$. An increase in compressive strength was observed with the addition of palm oil clinker to the mix until the optimum level of replacement. In case of mix proportions exceeding $20 \%$, palm oil clinker was found to negatively impact the development of compressive strength. The positive response of the concrete with $20 \%$ replacement of fine aggregate using palm oil clinker should encourage the use of such concrete in construction to aid waste management around the world.

\section{References}

[1] M. Adaway and Y. Wang, "Recycled glass as partial replacement for fine aggregate in structural concreteEffects in compressive strength," Electronic Journal of Engineering Structural Engineering, 14(1), pp. 116$122,2015$.

[2] Sumeet and Prof. Seetharam Munnur, "Study on strength and durability of concrete with partial replacement of fine aggregate by pond ash," International Journal for Scientific Research and Development, 2(11), pp. 296-299, 2015.

[3] Bashar S.Mohammed, Khandaker M. Anwar Hossain, W.L.Foo and M. Abdullahi, "Rapid chloride permeability test on light weight concrete made with oil palm clinker," International Journal of Engineering Research and Applications, 1(4), pp. 1863-1870, 2011.

[4] Divakar.Y, Manjunath.S and Dr.M.U.Aswath, "Experimental investigation on behaviour of concrete with the use of granite fines," International Journal of Advanced Engineering Research and Studies, 1(4), pp. 84-87, 2012.

[5] K. Muthusamy, N.A. Zulkepli and F.Mat Yahaya, "Exploratory study of palm oil shell as partial sand replacement in concrete," Research Journal of Applied Sciences ,Engineering and Technology,5(7), pp. 2372 2375, 2013 